THE COST AND RETURNS STRUCTURES OF MAJOR VEGETABLES

UNDER DIFFERENT SUPPLY CHAINS IN BENGALURU RURAL

\title{
DISTRICT OF KARNATAKA
}

\author{
R. $\operatorname{KIRAN}^{1} \&$ S. D. SIVAKUMAR ${ }^{2}$ \\ ${ }^{I}$ Research Scholar, Department of Agricultural and Rural Management, TNAU, Coimbatore, Tamil Nadu, India \\ ${ }^{2}$ Professor and Head, Department of Social sciences, ADAC \& RI Trichy, TNAU, Tamil Nadu, India
}

The study was undertaken with an objective to quantify the comparative economics of vegetables, under different vegetable supply chains in Bengaluru's, rural district of Karnataka. A sample of 180 farmers was selected using random sampling method and, data was collected through personal interview method. The tabular analysis were employed for analysis of data. Among the different vegetable supply chains major vegetables cultivated areidentified by conducting a pilot survey in the study area, two major vegetables viz., tomato and beans were selected for the studybased on maximum production and major vegetables procured. Results found that, among the three supply chains, per acre cost of cultivation of tomato was high for HОРСОМS farmers, share of total variable cost to the total cost was also higher in the case of HOPCOMS farmers followed by Reliance Fresh and traditional farmers respectively. The HOPCOMS farmers realized relatively higher levels of net returns due to high price for the produce and better management practices. B: $C$ ratio was high for HOPCOMS (3.25) followed by Reliance Fresh (2.66) and traditional (2.37) farmers and per acre cost of cultivation of bean was high for Reliance Fresh farmers, the share of total variable cost to the total cost was also higher, in the case of Reliance Fresh farmers followed by traditional farmers and HOPCOMS farmers, respectively. The net returns were high for reliance fresh farmers than HOPCOMS and traditional farmers. There was not much variation in both HOPCOMS (2.95) and Reliance Fresh (2.94) farmers, with respect to the returns per rupee of investment, and traditional farmers (2.29). The results of the study through light on and enable the farmers and extension agencies, to plan for the appropriate vegetable cultivation.

KEYWORDS: Cost and Returns, Vegetable production and Vegetable supply chains
\end{abstract}

Received: Oct 10, 2017; Accepted: Oct 30, 2017; Published: Nov 22, 2017; Paper Id.: IJASRDEC201743

\section{INTRODUCTION}

The horticulture sector has been a driving force, in stimulating growth in Indian agriculture. India is currently producing 277.7 million tonnes of horticulture produce from an area of 23.2 million hectares, which has surpassed the estimated food grain production of 257 million tonnes. Though, the production of food grains and horticultural produce are not meaningfully comparable, due to fundamental differences in the nature of their farming, characteristics of produce, nature of land requirements, and most importantly, their nutritional purpose and value, it has come to light that, horticultural farming is much productive and gainful. The productivity of horticultural crops has increased by about 34 percent, between 2004-05 and 2014-15 (Directorate of Economics \& Statistics, 2016)

India is the second largest producer of vegetables, after China and is a leader in the production of 
vegetables like peas and okra. Besides, India occupies the second position in terms of production of brinjal, cabbage, cauliflower and onion and the third position, in the production potato and tomato in the world (NHB 2015-16), with the gradual development of commercialized agriculture; marketing of farm products has assumed greater importance in recent years. Therefore, marketing is of utmost importance and demands special attention in case of perishable commodities like fruits and vegetables. Vegetables occupied an area of 9.5 million hectares during 2014-15 with a total production of 167 million tonnes having average productivity of 17.6 tonnes per hectare. Vegetable production registered a quantum jump of 66 per cent between 2001-02 and 2014-15 (Directorate of Economics \& Statistics, 2016)

The major vegetable crops grown in the country are potato, tomato, onion, brinjal, cabbage, cauliflower, peas, okra, chillies, beans, melons, etc. West Bengal has been maintaining the lead in vegetable production in the country, contributing about 16 per cent to total production, while Uttar Pradesh is producing almost 14 per cent of vegetables in the country with the difference being that the productivity of vegetables in Uttar Pradesh is as high as 21 tonnes per hectare against 19 tonnes per hectare in West Bengal. Other leading vegetable producing states are Bihar with an 8.6 per cent share, Madhya Pradesh with an 8.75 percent share, Gujarat with a 7 percent share, Odisha with a 6 percent share, Karnataka with a 5 percent share, Tamil Nadu with a 3.4 percent share and others. Amongst vegetables, potato is the most cultivated vegetable accounting for 27 percent of the total production of vegetables in the country, followed by onion (11 percent), tomato (10 percent), brinjal ( 7 percent), cabbage ( 5 percent), cauliflower ( 5 percent), peas ( 3 percent) and others in the country (Directorate of Economics \& Statistics, 2016)

Per capita availability of vegetables in India is $357 \mathrm{gm} /$ person/day, which is helping in fighting malnutrition. (Directorate of Economics \& Statistics, 2015-16). At all-India level, monthly per capita consumption of vegetables was estimated as Rs.94.62 in rural India (6.6\% of rural MPCE) and Rs.121.70 in urban India (4.6\% of urban MPCE). Consumption of carrots, lemons, cauliflowers, cabbages, tomatoes, lady's fingers and beans was appreciably more common in urban areas of the country, while potatoes, onions, gourds/pumpkins and brinjal were consumed by a greater percentage of households in rural areas. The average rural Indian consumed about $1 \mathrm{~kg} 965 \mathrm{gm}$ of potatoes a month, about $350 \mathrm{gm}$ more than the average urban resident. Total consumption of vegetables per person per month on the basis of these estimates (leaving out lemons) comes to around $6.8 \mathrm{~kg}$, for both rural and urban sectors. (NSSO data 2015-16)

\section{METHODOLOGY}

Bangalore city was the hub of retail revolution having many fruit and vegetable markets operating from a long period of time. Also, many supply chain formats have opened their outlets in the city at many places. The retail formats have made Bangalore as their focal point of the managerial operations. Many vegetable growing districts surrounded the Bangalore city, including Bangalore rural district. Farmers growing their produce in these districts, bring their produce to local vegetable markets and to emerging retail formats, established in Bangalore.

Bengaluru rural district is a major fruits and vegetables production belts in Karnataka state, area and production of vegetables constituted for 8,821 ha and 1, 65,234 M. Tones 2014-15. The district is located in $30 \mathrm{Kms}$, away from Bengaluru metropolitan city, thereby meeting significant portion of the city's demand for fruits and vegetables. The modern retail outlets have opened procurement/ collection centres in the district, in order to take advantage of adequate supply of fresh and quality agricultural and horticultural produce. To evaluate the objective of the study, random sampling technique was adopted. Mainly, three models of supply chain techniques were selected. They were, Horticultural 
Producers' Co-operative Marketing and Processing Society Ltd. (HOPCOMS) supply chain, Reliance Fresh supply chain and traditional marketing channel. Doddaballapura and Hosakote taluks of Bengaluru rural district was randomly selected, for studying Supply chain management in vegetable marketing, due to presence of procurement centres in the taluks and maximum vegetable production.

Among the different vegetable supply chains, major vegetables identified by conducting a pilot survey in the study area, two major vegetables viz., tomato and beans were selected, based on maximum the production and major vegetables procured in the study area. The economics of major vegetables under different vegetable supply chain was analysed, by using measures of central tendencies like mean, percentages etc.

For the study, in each taluk 90 farmers were selected, of which 30 member-farmers of HOPCOMS, 30 registered farmers of Reliance Fresh, who are supplying vegetables to procurement / collection centres and 30 Traditional farmers, resulting in a total size of 180 farmers were randomly selected. The reference year for the present study was $2016-2017$. Primary data were collected from the sample respondents during the months of December 2016 - January 2017. The respondents were contacted in person with a comprehensive pre-tested interview schedule and required information collected from them.

\section{UNITS OF MEASUREMENT}

The methods of measuring certain important variables are described below.

\section{Cost of Cultivation}

To estimate the costs and returns from cultivation any crop production activity, it is necessary to know about the concepts. The various concepts used are presented below for better understanding.

\section{Costs}

The total costs was divided into two broad classes

- Variable cost

- $\quad$ Fixed cost

The method adopted for computing the different cost items is described below.

\section{Variable Costs}

These were the costs incurred by the farmers for the crop enterprise, which were productive. Broadly, these were the actual costs along with incidental charges incurred towards labour and material costs.

- Seeds: The actual purchase price plus transportation costs incurred, if any. Farm produced seeds were imputed at prevailing market rates.

- Farmyard Manure: It was valued at the actual purchase price and self-produced FYM was valued at market prices.

- Fertilizers: Cost incurred in the purchase of fertilizers plus transport and other incidental charges.

- Labour: Hired labour was accounted for at the actual wages paid by the farmers. Family human labour was 
imputed at the prevailing wage rates. Women labour used in all crop enterprises was converted into mandays.

- Plant protection chemicals (PPC): Cost incurred in the purchase of plant protection chemicals plus transport and other incidental charges.

- Mulching: cost incurred in the purchase of the mulching material plus transport and other incidental charges.

- Interest on Working Capital: This was calculated on the entire working cost of the enterprise, at the prevailing bank rate of interest @ 12 percent per annum.

\section{Fixed Costs}

- Land Rent: The prevailing land rents for agricultural enterprises were imputed for the sample, since all land holdings were observed to be owner operated.

- Depreciation: The depreciation rates, life span and junk value for various agricultural implements and machinery were decided in consultation with the respondents. Consequently, the depreciation was calculated using the straight-line method as shown below.

Depreciation $=\quad$ Purchase value - Junk value

Life span

\section{Total Cost of Cultivation}

Cost of cultivation include variable and fixed costs. Variable costs include the cost of seed, FYM, fertilizers, human labour, chemicals, mulching and interest on working capital. Fixed cost comprised of depreciation and land rent.

\section{Cost of production per tonne}

It was calculated by dividing the total cost per acre by the yield per acre of vegetables (in tonnes)

\section{Returns}

\section{Gross Returns}

Gross returns were computed on the basis of actual prices at which individual farmers sold their produce. In order to arrive at gross returns per acre, the total gross returns were divided by the total cropped area devoted to a given crop.

\section{Net returns}

It was calculated by taking into account gross returns subtracting the total cost.

\section{RESULT AND DISCUSSIONS}

\section{Costs and Returns structure of Tomato Under Different Supply Chains}

The cost incurred and returns realized from tomato under different supply chains and their shares to total cost and returns were calculated and presented in Table01.

Among the three supply chains, per acre cost of cultivation was high for HOPCOMS farmers, share of total variable cost to the total cost was also higher in the case of HOPCOMS farmers (Rs. 89186.67/acre) followed by Reliance Fresh (Rs. 87356.16/acre) and traditional farmers (Rs. 85262.34/acre) respectively. This may be attributed to use of more 
labour by HOPCOMS farmers. Bala et al., (2011) in their study on the costs and returns structure for the production of major off-season vegetables in Kullu reported that, vegetables are labour intensive crops and incur significantly high costs on human labour. Higher gross returns resulted in higher profit over variable costs in the case of HOPCOMS farmers (Rs. 417116.67/acre) as compared to Reliance Fresh farmers (Rs. 337333.33/acre) and traditional farmers (Rs. 283066.67/acre). The HOPCOMS farmers realized relatively higher levels of net returns due to high price for the produce and better management practices. B: C ratio was high for HOPCOMS (3.25), followed by Reliance Fresh (2.66) and traditional (2.37) farmers.

\section{Costs and Returns Structure of Beans Under Different Supply Chains}

The cost incurred and returns realized from beans under different supply chains and their shares to total cost and returns were calculated and presented in Table 02.

Among the three supply chains, per acre cost of cultivation was high for Reliance Fresh farmers, the share of total variable cost to the total cost was also higher in the case of Reliance Fresh farmers (Rs. 58003.38/acre), followed by traditional farmers (Rs. 55857.79/acre) and HOPCOMS farmers (Rs. 55265.85/acre). Is this because of higher cost incurred for wire and bamboo sticks. The net returns were high for Reliance Fresh farmers (Rs.189450.37/acre)than HOPCOMS and traditional farmers, due to higher yield and price. It is clear that there was not much variation in both HOPCOMS (2.95), Reliance Fresh (2.94) farmers with respect to the returns per rupee of investment, and traditional farmers (2.29).

Table 1: Costs and Returns Structure of Tomato under Different Supply Chains (Rs/ac) (Number of farmers)

\begin{tabular}{|c|c|c|c|c|c|c|c|c|c|c|c|}
\hline \multirow{2}{*}{$\begin{array}{l}31 \\
\text { No }\end{array}$} & \multirow{2}{*}{ Parteselars } & \multirow{2}{*}{ Lnit } & \multicolumn{3}{|c|}{$\begin{array}{l}\text { Deliance Frah } \\
\qquad(m-30)\end{array}$} & \multicolumn{3}{|c|}{$\begin{array}{c}\text { honcons } \\
(m-30)\end{array}$} & \multicolumn{3}{|c|}{$\begin{array}{c}\text { Traditiganal } \\
(n-30)\end{array}$} \\
\hline & & & $0 \%$ & ralac & Pereent & $\theta$ & ralue & Dereent & 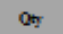 & ralue & Percent \\
\hline 1 & $\begin{array}{l}\text { Hamus } \\
\text { habour }\end{array}$ & Mandax & 47.46 & 3048.72 & 6.34 & 51.10 & 9303.56 & 7.71 & 50.80 & 8540.40 & 7.15 \\
\hline 2 & $\begin{array}{l}\text { Machine } \\
\text { parter }\end{array}$ & Rolker & 1.64 & : 300.41 & 1.03 & 1.72 & 1375.12 & 1.07 & 1.72 & 1373.74 & 2.15 \\
\hline 3 & Scedling & Nember & 7140.59 & 6434.59 & 5.07 & 7003.00 & 6939.28 & 4.93 & $8^{7393.8}$ & 6679.00 & 5.58 \\
\hline 4 & FYM & $m$ & 1.30 & 3243.93 & 2.56 & 1.26 & 3157.39 & 2.46 & 2.33 & 3933.39 & 2.79 \\
\hline 5 & Ferfilixern & $K_{q}$ & 143.50 & 5293.41 & 4.16 & 142.50 & 5346.90 & 4.17 & 152.50 & 5432.83 & 4.53 \\
\hline 6 & $\begin{array}{l}\begin{array}{l}\text { Mast } \\
\text { protectias } \\
\text { Chemiah }\end{array} \\
\end{array}$ & $\mathrm{Da}$ & & 7990.65 & 6.20 & & 7846.89 & 6.12 & & 7658.50 & 6.40 \\
\hline 7 & Mulching & $\mathrm{Rn}$ & & 45407.95 & 35.75 & & 45617.22 & 35.55 & & 49050.02 & 30.30 \\
\hline 3 & $\begin{array}{l}\text { Intercat on } \\
\text { markiags } \\
\text { capital \& } \\
12 \%\end{array}$ & Percent & & 9627.56 & 7.58 & & 9555.71 & 7.45 & & 9135.25 & 7.64 \\
\hline 9 & \begin{tabular}{|l|} 
Tatal \\
rarizble \\
cant \\
\end{tabular} & & & 37356.16 & 63.77 & & 30186.67 & 60.50 & & 35262.34 & 71.20 \\
\hline \multirow[t]{3}{*}{10} & Fixed cont & & & & & & & & & & \\
\hline & $\begin{array}{l}\text { Rentel ratuse } \\
\text { of hied }\end{array}$ & & & 15000.00 & 11.81 & & 15000.00 & 11.60 & & 15000.00 & 12.54 \\
\hline & Defeciatise & & & 24672.58 & 19.42 & & 24134.36 & 18.81 & & 19345.01 & 16.17 \\
\hline 11 & $\begin{array}{l}\text { Tatal fred } \\
\text { cant }\end{array}$ & & & 39672.58 & 31.23 & & 30134.36 & 30.50 & & 34345.01 & 28.71 \\
\hline 12 & Tatal cant & & & 127028.74 & 100.00 & & 120321.04 & 200.00 & & 119607.35 & 100.00 \\
\hline 13 & Yield & 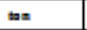 & 29.33 & & & 28.77 & & & 25.73 & & \\
\hline 14 & $\begin{array}{l}\text { Cont of } \\
\text { production } \\
\text { per tansas }\end{array}$ & $\Rightarrow=$ & & 4390.53 & & & 4460.75 & & & 4647.95 & \\
\hline 14 & Pries & $\mathrm{Dan} / \mathrm{K}_{\mathrm{q}}$ & 14.50 & & & 24.50 & & & 11.00 & & \\
\hline \multirow[t]{3}{*}{15} & Retarn & & & & & & & & & & \\
\hline & $\begin{array}{l}\text { Conn } \\
\operatorname{man}\end{array}$ & & & งรางงง.3ง & & & 417116.67 & & & 293066.67 & \\
\hline & Net $x$ stam & & & 210304.98 & & & 289795.63 & & & 169450.32 & \\
\hline 16 & $\begin{array}{l}\text { Retares per } \\
\text { rapoe of } \\
\text { expenditare }\end{array}$ & & & 2.66 & & & 3.25 & & & 2.37 & \\
\hline
\end{tabular}


Table 2: Costs and returns structure of Beans under Different Supply Chains (Rs/ac)(Number of farmers)

\begin{tabular}{|c|c|c|c|c|c|c|c|c|c|c|c|}
\hline \multirow{2}{*}{$\begin{array}{l}\text { SI. } \\
\text { No }\end{array}$} & \multirow{2}{*}{ Particulars } & \multirow{2}{*}{ Unit } & \multicolumn{3}{|c|}{$\begin{array}{l}\text { Reliance Fresh } \\
\qquad(\mathrm{n}=30)\end{array}$} & \multicolumn{3}{|c|}{$\begin{array}{c}\text { HOPCOMS } \\
(\mathrm{n}=30)\end{array}$} & \multicolumn{3}{|c|}{$\begin{array}{l}\text { Traditional } \\
(\mathrm{n}=30)\end{array}$} \\
\hline & & & Qty & value & Percent & Qty & value & Percent & Qty & value & Percent \\
\hline 1 & $\begin{array}{l}\text { Human } \\
\text { labour }\end{array}$ & Mandays & 63.89 & 10703.45 & 1096 & 65.10 & 1069451 & 11.66 & 67.06 & 11152.74 & 12.60 \\
\hline 2 & $\begin{array}{l}\text { Machine } \\
\text { power }\end{array}$ & $\mathrm{Rs} / \mathrm{hr}$ & 1.86 & 1493.10 & 1.53 & 1.75 & 1397.80 & 1.52 & 1.81 & 1451.07 & 1.57 \\
\hline 3 & Seed & $\mathrm{Kg}$ & 6.60 & 4288.51 & 439 & 6.78 & 4407.14 & 4.80 & 6.57 & 4270.76 & 4.62 \\
\hline 4 & FYM & ton & 1.67 & 3908.05 & 4.00 & 1.19 & 2967.03 & 323 & 150 & 4270.76 & 4.62 \\
\hline 5 & Fertilizers & $\mathrm{Kg}$ & 21700 & 5326.67 & 5.45 & 19450 & 4598.90 & 5.01 & 15300 & 509523 & 5.51 \\
\hline 6 & $\begin{array}{l}\text { Plant } \\
\text { protection } \\
\text { Chemicals } \\
\end{array}$ & Rs & & 6436.78 & 6.59 & & 5978.02 & 6.52 & & 5541.77 & 599 \\
\hline 7 & $\begin{array}{l}\text { Wire and } \\
\text { bamboo } \\
\text { sticlss }\end{array}$ & Rs & & 19632.18 & 20.10 & & 19301.10 & 21.04 & & 18090.69 & 19.56 \\
\hline 8 & $\begin{array}{l}\text { Interest on } \\
\text { worling } \\
\text { capital a } \\
12 \%\end{array}$ & Percent & & 6214.65 & 636 & & 592134 & 6.45 & & 5984.76 & 6.47 \\
\hline 9 & $\begin{array}{l}\text { Total } \\
\text { variable } \\
\text { cost } \\
\end{array}$ & & & 5800338 & 59.40 & & 55265.85 & 60.24 & & 55857.79 & 60.38 \\
\hline \multirow[t]{3}{*}{10} & Fixed cost & & & & & & & & & & \\
\hline & $\begin{array}{l}\text { Rental vahe } \\
\text { of land }\end{array}$ & & & 1500000 & 1536 & & 15000.00 & 1635 & & 15000.00 & 1621 \\
\hline & Depreciation & & & 2464625 & 25.24 & & 2147241 & 23.41 & & 21650.17 & 23.40 \\
\hline 11 & $\begin{array}{l}\text { Total fixed } \\
\text { cost }\end{array}$ & & & 3964625 & 40.60 & & 3647241 & 39.76 & & 36650.17 & 39.62 \\
\hline 12 & Total cost & & & 97649.63 & 100.00 & & 9173825 & 100.00 & & & 100.00 \\
\hline 13 & Yield & ton & 8.70 & & & 8.32 & & & 6.85 & & \\
\hline 14 & $\begin{array}{l}\text { Cost of } \\
\text { production } \\
\text { per tonne }\end{array}$ & & & 11224.10 & & & 11030.65 & & & 1351139 & \\
\hline 14 & Price & $\mathrm{Rs} / \mathrm{Kg}$ & 33.00 & & & 3250 & & & 31.00 & & \\
\hline \multirow[t]{3}{*}{15} & Returus & & & & & & & & & & \\
\hline & $\begin{array}{l}\text { Gross } \\
\text { retums }\end{array}$ & & & 28710000 & & & 27029167 & & & 21224667 & \\
\hline & Net retums & & & 18945037 & & & 17855342 & & & 119738.70 & \\
\hline 16 & $\begin{array}{l}\text { Returns per } \\
\text { rupee of } \\
\text { expenditure }\end{array}$ & & & 294 & & & 2.95 & & & 2.29 & \\
\hline
\end{tabular}

\section{Constraints Faced by the Farmers in the Study Area}

Constraints faced by the farmers in the study area are grouped under two heads, namely, production constraints and marketing constraints and they are presented in the Table 3 and Table 4.

Table 3: Production Constraints of Sample Farmers in the Study Area (Number of Farmers)

\begin{tabular}{|c|c|c|c|c|c|c|c|}
\hline \multirow{3}{*}{$\begin{array}{l}\text { Sl. } \\
\text { No }\end{array}$} & \multirow{3}{*}{$\begin{array}{l}\text { Production } \\
\text { constraints }\end{array}$} & \multicolumn{6}{|c|}{ Vegetable Supply Chain } \\
\hline & & \multicolumn{2}{|c|}{$\begin{array}{l}\text { Reliance fresh } \\
\quad(n=60)\end{array}$} & \multicolumn{2}{|c|}{$\begin{array}{l}\text { HOPCOMS } \\
\qquad(\mathbf{n}=60))\end{array}$} & \multicolumn{2}{|c|}{$\begin{array}{l}\text { Traditional } \\
\qquad(n=60)\end{array}$} \\
\hline & & $\begin{array}{l}\text { Garrett's } \\
\text { Score } \\
\end{array}$ & Rank & $\begin{array}{l}\text { Garrett's } \\
\text { Score }\end{array}$ & Rank & $\begin{array}{l}\text { Garrett's } \\
\text { Score } \\
\end{array}$ & Rank \\
\hline 1 & Expensive inputs & 66.58 & $\mathrm{I}$ & 52.63 & III & 53.32 & IV \\
\hline 2 & $\begin{array}{l}\text { Damage by pests and } \\
\text { diseases }\end{array}$ & 66.38 & II & 68.95 & I & 63.37 & II \\
\hline
\end{tabular}


Table 3: Contd.,

\begin{tabular}{|c|c|c|c|c|c|c|c|}
\hline 3 & Wages are high & 63.35 & III & 51.42 & IV & 64.38 & I \\
\hline 4 & $\begin{array}{l}\text { Scarcity of owned } \\
\text { fund }\end{array}$ & 49.57 & IV & 54.28 & II & 51.42 & V \\
\hline 5 & $\begin{array}{lr}\text { Lack of technical } \\
\text { knowledge } \\
\text { production, } \\
\text { quality control }\end{array}$ & 46.82 & V & 51.40 & V & 55.57 & III \\
\hline 6 & $\begin{array}{l}\text { Uneconomic land } \\
\text { holding }\end{array}$ & 40.80 & VI & 33.87 & VII & 36.47 & VII \\
\hline 7 & $\begin{array}{l}\text { Uneven distribution of } \\
\text { rainfall }\end{array}$ & 40.67 & VII & 37.08 & VI & 37.63 & VI \\
\hline
\end{tabular}

In the case of Reliance Fresh the results of Garret's ranking shows that major constraints in production of vegetables were expensive inputs, damage by pests and diseases, and wages are high were ranked I, II and III respectively.

While in the case of HOPCOMS, the farmers reported that major constraints in production of vegetables were damage by pests and diseases, scarcity of owned fund and expensive inputs were ranked I, II and III respectively.

The traditional farmers reported that major constraints in production of vegetables were wages are high, damage by pests and diseases and lack of technical knowledge in production and quality control were ranked I, II and III respectively.

The overall results of production constraints faced by the sample farmers revealed thatdamage by pests and diseases, due to attack of fruit borer, leaf miner thrips and stem borer were major pests and powdery mildew, downey mildew and anthracnose were major diseases in vegetable cultivation. The farmers were facing problem of expensive inputs was observed in the Reliance Fresh and HOPCOMS, indicating higher expenditure on inputs like labour, seeds, fertilizers and FYM. High wage rate due to non-availability of enough labour during critical farming operations was the major problem faced by the all sample farmers, under different vegetable supply chain.

Most of the traditional farmers opined lack of technical knowledge in production and quality control. due to lack of technical support on scientific method of production, harvest and post-harvest practices of vegetables from time to time such as harvest at full maturity, harvest at specific intervals, cleaning, washing, grading and filed packing. Small land holdings resulted due to fragmentation and sub-division of land, which was uneconomical for cultivation, Non-availability of sufficient productive non-farming opportunities in the study area may have resulted in low cash reserve with the farmers. In the study area farmers are facing the problem of uneven distribution of rainfall affecting the vegetable production, which is beyond their control. 
Table 4: Marketing Constraints of Sample Farmers in the Study Area (Number of Farmers)

\begin{tabular}{|c|c|c|c|c|c|c|c|}
\hline \multirow{3}{*}{$\begin{array}{l}\text { Sl. } \\
\text { No }\end{array}$} & \multirow{3}{*}{ Marketing constraints } & \multicolumn{6}{|c|}{ Vegetable supply chain } \\
\hline & & \multicolumn{2}{|c|}{$\begin{array}{l}\text { Reliance fresh } \\
(n=60)\end{array}$} & \multicolumn{2}{|c|}{$\begin{array}{c}\text { HOPCOMS } \\
(n=60)\end{array}$} & \multicolumn{2}{|c|}{$\begin{array}{l}\text { Traditional } \\
(\mathrm{n}=60)\end{array}$} \\
\hline & & $\begin{array}{c}\text { Garrett's } \\
\text { Score }\end{array}$ & Rank & $\begin{array}{c}\text { Garrett's } \\
\text { Score }\end{array}$ & Rank & $\begin{array}{l}\text { Garrett's } \\
\text { Score }\end{array}$ & Rank \\
\hline 2.1 & Poor product handling & 68.93 & $\mathrm{I}$ & 47.45 & IV & 53.73 & $\mathrm{~V}$ \\
\hline 2.2 & $\begin{array}{l}\text { Perishability of the } \\
\text { produce }\end{array}$ & 65.93 & II & 45.55 & V & 38.25 & VI \\
\hline 2.3 & Price Fluctuation & 52.32 & III & 48.60 & III & 56.90 & II \\
\hline 2.4 & $\begin{array}{l}\text { Lack of marketing } \\
\text { infrastructure }\end{array}$ & 49.80 & IV & 57.20 & II & 53.87 & IV \\
\hline 2.5 & Poor product packaging & 43.10 & $\mathrm{~V}$ & 69.90 & I & 37.83 & VII \\
\hline 2.6 & High marketing costs & 41.10 & VI & 42.40 & VI & 59.43 & I \\
\hline 2.7 & $\begin{array}{l}\text { Inadequate of market } \\
\text { information }\end{array}$ & 33.47 & VII & 41.93 & VII & 56.18 & III \\
\hline
\end{tabular}

Table 4, Shows that Major marketing constraints faced by registered farmers of Reliance Fresh were poor product handling, perishability of the produce and price fluctuation were ranked I, II and III, respectively. While unloading, the vegetables were poorly handling by labours at Collection centre it leads wastage, hence proper care should be taken by labour while handling the produce

The member farmers of HOPCOMS reported that major constraints in marketing of vegetables were Poor product packaging, Lack of marketing infrastructure and price fluctuation were the major constraints in marketing of vegetables were ranked I, II and III respectively. Poor product packaging by the member farmers of HOPCOMS, it may lead to postharvest losses. HOPCOMS can be restored to supply packing materials to minimise post-harvest losses. HOPCOMS need to improve the infrastructure at CCs, i.e. proper building and other basic amenities.

In the case of traditional farmers the results of Garret's ranking shows that major constraints in marketing of vegetables were high marketing costs, price fluctuations, and Inadequate of market information were ranked I, II and III respectively. Price fluctuation and perishability of the produce were the major problems in the study area. seasonal nature of agricultural production leads to market glut at the time of harvest and arrival into the markets, ultimately leading to price crash owing to law of supply. Phasing of production would be a more sophisticated technique to avoid price risks. High marketing costs and lack of marketing infrastructures were the other associated problems, which can be addressed not at individual level but at societal level under, present situations developing scientific storage facilities for phasing of arrivals into the market would be of little solace towards price crashes. Similar results were also reported by Jabir and Sanjeev (2008), on Farmers perception on risk in fruits and vegetables production in Uttar Pradesh.

\section{CONCLUSIONS}

It was found that, among the three supply chains, per acre cost of cultivation of tomato was high for HOPCOMS farmers, share of total variable cost to the total cost was also higher in the case of HOPCOMS farmers followed by Reliance Fresh and traditional farmers respectively. The HOPCOMS farmers realized relatively higher levels of net returns due to high price for the produce and better management practices. B: C ratio was high for HOPCOMS (3.25) followed by 
Reliance Fresh (2.66) and traditional (2.37) farmers.

The results revealed that, among the three supply chains, per acre cost of cultivation of bean was high for Reliance Fresh farmers, the share of total variable cost to the total cost was also higher in the case of Reliance Fresh farmers followed by traditional farmers and HOPCOMS farmers respectively. The net returns were high for reliance fresh farmers than HOPCOMS and traditional farmers. There was not much variation in both HOPCOMS (2.95) Reliance Fresh (2.94) farmers with respect to the returns per rupee of investment, and traditional farmers (2.29). Efforts should be made through Reliance Fresh, HOPCOMS and Raitha Samparka Kendras, to utilize farm resources rationally and to enhance productivity and profitability. The results of the study through light on and enable the farmers and extension agencies, to plan for the appropriate vegetable cultivation.

Damage by pests \& diseases, expensive inputs, high wages and Most of the traditional farmers opined lack of technical knowledge in production and quality control were the major problems faced by the sample farmers in production. Major marketing constraints faced by registered farmers of Reliance Fresh were poor product handling, perishability of the produce, Poor product packaging, Lack of marketing infrastructure in HOPCOMS, High marketing costs and price fluctuations by traditional farmers. Hence, appropriate policies may be formulated for safe guarding the interest of the farmers.

\section{REFERENCES}

1. Bala, B., Sharma, N. and Sharma, R. K. (2011). Cost and Return Structure for the Promising Enterprise of Off-Season Vegetables in Himachal Pradesh. Agricultural Economics Research Review, 24: 141-148.

2. Directorate of Economics \& Statistics. (2016). State of Indian Agriculture. Ministry of Agriculture \& Farmers Welfare. Government of India.

3. Jabir ali. andSanjeev Kapoor. (2008). Farmers perception on risk in fruits and vegetables production: an empirical study of Uttar Pradesh. Agricultural Economics Research review (Conference Special) 21: 317-326.

4. National Horticulture Database. (2015-16). National Horticulture Board, Ministry of Agriculture, Government of India.

5. National Sample Survey Office. (2015-16). Household Consumption of Various Goods and Services in India 20ll-12. NSS 68th Round, Ministry of Statistics and Programme Implementation, Government of India. 
